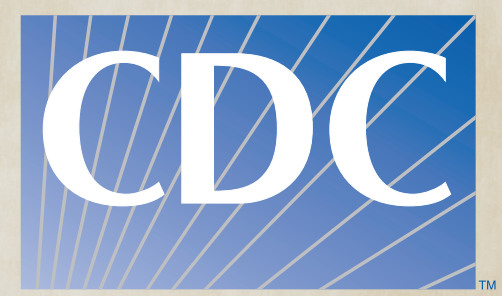

Workplace

Safety and Health

\title{
Evaluation of Radon
} Levels at a U.S. Government Facility Maine

\section{Mark M. Methner, PhD, CIH}

Health Hazard Evaluation Report HETA 2011-0031-3167 December 2012 
The employer shall post a copy of this report for a period of 30 calendar days at or near the workplace(s) of affected employees. The employer shall take steps to insure that the posted determinations are not altered, defaced, or covered by other material during such period. [37 FR 23640, November 7, 1972, as amended at 45 FR 2653, January 14, 1980]. 


\section{CONTENTS}

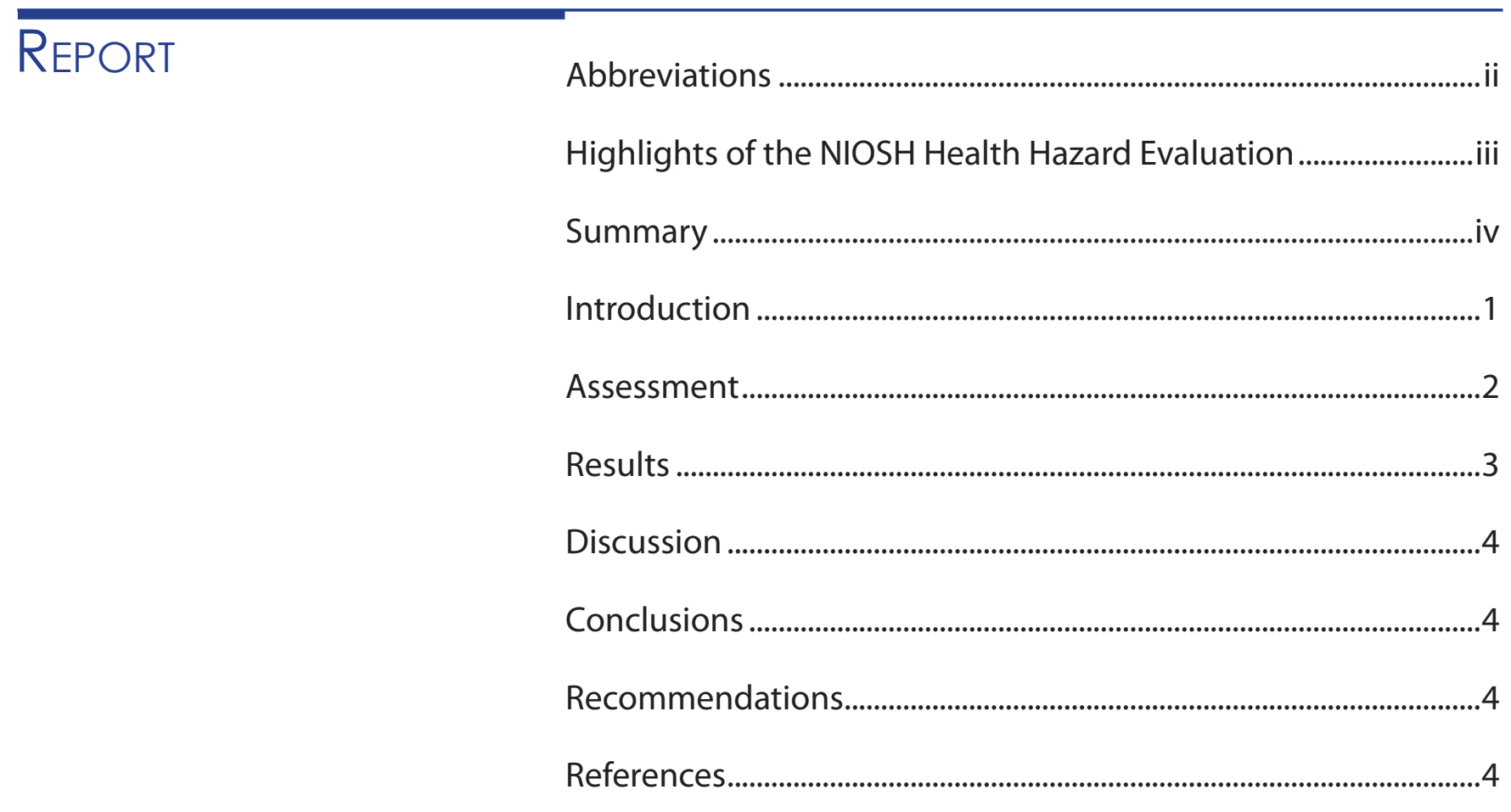


ABBREVIATIONS

ACGIH ${ }^{\circledR} \quad$ American Conference of Governmental Industrial Hygienists

CFR

Code of Federal Regulations

EPA

Environmental Protection Agency

HHE

Health hazard evaluation

NAICS

North American Industry Classification System

$\mathrm{NIOSH}$

National Institute for Occupational Safety and Health

OEL

Occupational exposure limit

OSHA

Occupational Safety and Health Administration

PEL

Permissible exposure limit

$\mathrm{pCi} / \mathrm{L}$

picoCuries per liter of air

REL

Recommended exposure limit

STEL

Short-term exposure limit

TLV®

Threshold limit value

TWA

Time-weighted average

WEEL ${ }^{\mathrm{TM}}$

Workplace environmental exposure level 


\section{HIGHLIGHTS OF THE NIOSH HEALTH Hazard Evaluation}

\section{The National Institute for Occupational Safety and Health (NIOSH) received a request for a health hazard evaluation at a government building in Maine. Union representatives of employees from a federal agency requested assistance in evaluating employee exposure to naturally-occurring radon inside the building.}

\section{What NIOSH Did}

- We measured radon levels from January 2012 to May 2012.

- We measured radon levels inside and outside the building.

\section{What NIOSH Found}

- Radon concentrations outdoors and in the occupied work area were below OSHA and EPA exposure limits.

- Radon concentrations in the basement were higher than in the work area or outdoors. Employees usually do not work in the basement.

\section{What Managers Can Do}

- Ensure employees minimize the time spent in the basement.

- Consider installing a ventilation system in the basement to remove radon if this space is ever used as an occupied work area.

\section{What Employees Can Do}

- Minimize the time spent in the basement. 


\section{A NIOSH investigator evaluated employee exposures to radon. We found that radon levels in the first floor work area were well below the OSHA PEL of $100 \mathrm{pCi} / \mathrm{L}$, and also below the much lower EPA residential guideline of $4 \mathrm{pCi} / \mathrm{L}$. However, radon levels in the basement were higher than on the first floor, but the basement was typically unoccupied. We recommend that employees minimize the time they spend in the basement to keep exposure to radon as low as practical. If the basement is ever used as a work space, installing a basement radon mitigation system should be considered.}

In December 2010, NIOSH received an HHE request from the union representing employees at a government facility in Maine. $\mathrm{NIOSH}$ was asked to evaluate employees' exposure to radon gas during normal work activities at the facility (e.g., inspecting vehicles and materials, collecting duties, and confiscating contraband). The primary employee health concern at this facility was exposure to naturally-occurring radon gas. We evaluated the facility on January 31-February 2, 2012. We observed work practices and measured radon levels in the occupied work areas and the typically unoccupied basement. The radon measurements were recorded at 10-minute intervals over approximately 48 hours. We also placed long-term Radtrak ${ }^{\circledR}$ radon detectors in the work area, basement, and outdoors; these detectors were collected on May 30, 2012, and analyzed by the manufacturer.

Radon levels averaged $0.8 \pm 1.7 \mathrm{pCi} / \mathrm{L}$ in the first floor work area and higher $(3.8 \pm 3.9 \mathrm{pCi} / \mathrm{L})$ in the basement on February 1-2, 2012 . The radon levels did not fluctuate substantially during the day. No detectable levels of radon were found in the outdoor inspection lane over a 4-month sampling period. Over 4 months, radon levels in the first floor work area averaged $0.6 \mathrm{pCi} / \mathrm{L}$, while the basement average was $7.5 \mathrm{pCi} / \mathrm{L}$. All of these radon levels are well below the OSHA PEL of $100 \mathrm{pCi} / \mathrm{L}$. The radon levels in the occupied first floor were also below the EPA residential guideline of $4 \mathrm{pCi} / \mathrm{L}$, but the levels in the unoccupied basement were above the EPA guideline. Following the principle of keeping exposures to ionizing radiation as low as possible, we recommend that employees minimize the time they spend in the basement.

Keywords: NAICS 921130 (Public finance activities), radiation, radon, radon progeny, exposure, Radtrak $\AA$ 
In December 2010, NIOSH received an HHE request from a union representative on behalf of employees at a government facility in Maine. NIOSH was asked to evaluate levels of radon in the workplace. The primary health concern at this facility involved inhalation exposure to naturally-occurring radon gas. We evaluated the facility on January 31, 2012-February 2, 2012. We observed work practices and measured radon levels in the work area and basement. The radon measurements were recorded at 10-minute intervals over approximately 48 hours. We placed long-term Radtrak® radon detectors in the work area, basement, and outdoors; these detectors were collected on May 30, 2012, and analyzed by the manufacturer. This report contains our findings and recommendations from our evaluation of radon gas at the facility.

The brick and wood facility was constructed in 1931 and was leased from the U.S. government. It had two floors above grade and a poured concrete basement. Heat was provided by an oil-fired boiler that supplied hot water to perimeter baseboard radiators. The building did not have central air-conditioning, but several rooms had window-mounted units. Employees could also open windows. The basement was used primarily for storage, but also housed supplies, electronic equipment, and the oil-fired boiler. The second floor was used exclusively for storage.

The first floor was divided into two offices and a work area where employees monitored vehicles and people entering the United States from Canada 24 hours per day. Employees spent about $80 \%$ of their 8 -hour work shift in the first floor offices, and the remainder of their shift was spent outdoors inspecting vehicles. At the time of our evaluation 29 employees worked rotating shifts between this facility and others along the border. On average, four to six employees worked 8-hour work shifts at this facility.

\section{Radon and its Health Effects}

Radon is a colorless, tasteless radioactive gas that is formed via the radioactive decay of radium. Radium is common in many soils and rocks, though its concentration can vary widely. Because radon is a gas, it can leave the soil or rock where it formed and enter the surrounding air. Therefore, radon levels can build up when ventilation rates are low or when a large amount of radium is present. 
INTRODUCTION (CONTINUED)
Cancer is the major effect of concern from radium and radon radionuclides [ATSDR 1990; DOE 1995]. Inhalation is the primary route of radon exposure. Exposure to radon increases a person's risk for lung cancer, and smokers exposed to radon are at greater risk for lung cancer (approximately 10 to 20 times) than are similarly exposed nonsmokers [ATSDR 1990].

Across the United States, background concentrations of radon in outdoor air range from 0.003 to $2.6 \mathrm{pCi} / \mathrm{L}$ and are higher in areas with uranium and thorium deposits or granite formations [DOE 1995]. During the winter of 1988-1989, the EPA used charcoal canisters in a 2 to 7 day measurement survey for radon in 839 homes across all 16 counties in Maine. The EPA found that in the county where this facility is located, along with four other counties in central and southern Maine, the average radon concentrations exceeded $4 \mathrm{pCi} / \mathrm{L}$ [EPA 1993]. The EPA recommends taking corrective measures when in-home radon levels exceed $4 \mathrm{pCi} / \mathrm{L}$. However, the recommendations and action levels for indoor radon provided by the EPA are neither enforceable nor applicable for a workplace environment. For occupational settings, the OSHA PEL is $100 \mathrm{pCi} / \mathrm{L}$ for a 40 hour exposure in any workweek of 7 consecutive days. See the Appendix for information on exposure limits.

\section{Short-term Real-time Measurements}

We measured radon in the first floor work area and basement areas using a PRISM Model 597-PX3 monitor (alphaNUCLEAR®, Saskatoon, Saskatchewan, Canada). The portable monitor was set to data-log radon levels every 10 minutes over approximately 48 hours. The limit of detection of this instrument is $0.1 \mathrm{pCi} / \mathrm{L}$.

\section{Long-term Passive Measurements}

We used Radtrak detectors (Landauer, Inc., Glenwood, Illinois) to passively measure radon levels over a 4 -month period. These detectors contain a polymer film inside a perforated metal container. Radon diffuses into the container and decays into electrically charged daughter products, which stick to the polymer film and are subsequently counted by the manufacturer. The limit of detection is $30 \mathrm{pCi} / \mathrm{L} /$ day (the equivalent of 30 days at $1 \mathrm{pCi} / \mathrm{L}$, or 15 days at $2 \mathrm{pCi} / \mathrm{L}$, etc). Our detectors were exposed for 121 
ASSESSMENT

(CONTINUED)

days (January 31, 2012-May 30, 2012), resulting in a minimum detectable concentration of $0.3 \mathrm{pCi} / \mathrm{L}$. Detectors were placed (in triplicate) approximately 5 feet above the floor in the basement, in the first floor work area, and outdoors in the vehicle inspection lanes. We also collected four field blanks.

RESULTS

Radon concentrations averaged $0.8 \pm 1.7 \mathrm{pCi} / \mathrm{L}$ in the work area, on the basis of 273 measurements across 48 hours. Average radon concentrations in the basement were higher, $3.8 \pm 3.9 \mathrm{pCi} / \mathrm{L}$ on the basis of 290 measurements. Radon levels did not fluctuate substantially throughout the day.

Table 1 shows the results from the passive monitoring across the 121-day period. Results for the outdoor detectors were below the limit of detection $(0.3 \mathrm{pCi} / \mathrm{L})$, while levels in the work area were slightly higher $(0.6 \mathrm{pCi} / \mathrm{L})$. Results for the detectors placed in the basement averaged $7.5 \mathrm{pCi} / \mathrm{L}$ over the 121-day sampling period.

Table 1. Radon levels measured between January 31, 2012 and May 30, 2012

\begin{tabular}{ll}
\hline Sample Location & Average Radon Concentration (pCi/L) \\
\hline \multirow{3}{*}{ Outdoors/inspection lane } & $\mathrm{ND}^{*}$ \\
& $\mathrm{ND}^{*}$ \\
& $\mathrm{ND}^{*}$ \\
\hline \multirow{2}{*}{ First floor work area } & 0.6 \\
& 0.6 \\
& 0.6 \\
\hline & 7.2 \\
Basement & 7.5 \\
\hline
\end{tabular}

*ND - Not detected; the levels were below the minimum detectable concentration of $0.3 \mathrm{pCi} / \mathrm{L}$. All field blanks were ND. 
All radon levels measured during this evaluation were well below the OSHA PEL of $100 \mathrm{pCi} / \mathrm{L}$. Additionally, the radon levels in the occupied work areas on the first floor of the facility were below the much lower EPA residential guideline of $4 \mathrm{pCi} / \mathrm{L}$. Although the average radon levels in the unoccupied basement $(7.5 \mathrm{pCi} / \mathrm{L})$ exceeded the EPA residential guideline, the basement was typically unoccupied. Furthermore, a radon level of $7.5 \mathrm{pCi} / \mathrm{L}$ is not high for this area of Maine [EPA 1993]. Nearly 30\% percent of the homes analyzed in the state of Maine during the EPA survey of 1988-1989 exceeded $4 \mathrm{pCi} / \mathrm{L}$, and the homes in the county where this facility is located averaged about $5 \mathrm{pCi} / \mathrm{L}$.

\section{CONCLUSIONS}

Radon levels measured during this evaluation in the occupied work areas of the facility were well below the OSHA PEL of $100 \mathrm{pCi} / \mathrm{L}$, and even below the much lower EPA residential guideline of $4 \mathrm{pCi} / \mathrm{L}$. Although radon levels in the basement were higher than the first floor, this area of the building was typically unoccupied.

On the basis of our findings, we recommend that employees minimize the time they spend in the basement. This recommendation is based upon the principle of keeping personal exposures to any ionizing radiation as low as practical. Additionally, if the basement is ever converted into a space where employees may spend more of their work shift, the managers should consider installing a basement radon mitigation system.

ATSDR [1990]. Toxicological profile for radon TP-90-23. Atlanta, GA: U.S. Department of Health and Human Services, Agency for Toxic Substances and Disease Registry.

DOE [1995]. Science, society and America's nuclear waste: ionizing radiation. Unit 2, 1st ed. Washington, DC: U.S. Department of Energy Publication DOE/RW-0362 SR.

EPA [1993]. EPA's map of radon zones. United States Environmental Protection Agency. Air and Radiation (6604J). $402-$ R-93-039. September 1993. 


\section{Appendix: Occupational Exposure Limits and Health Effects}

In evaluating the hazards posed by workplace exposures, NIOSH investigators use both mandatory (legally enforceable) and recommended OELs for chemical, physical, and biological agents as a guide for making recommendations. OELs have been developed by federal agencies and safety and health organizations to prevent the occurrence of adverse health effects from workplace exposures. Generally, OELs suggest levels of exposure that most employees may be exposed to for up to 10 hours per day, 40 hours per week, for a working lifetime, without experiencing adverse health effects. However, not all employees will be protected from adverse health effects even if their exposures are maintained below these levels. A small percentage may experience adverse health effects because of individual susceptibility, a preexisting medical condition, and/or a hypersensitivity (allergy). In addition, some hazardous substances may act in combination with other workplace exposures, the general environment, or with medications or personal habits of the employee to produce adverse health effects even if the occupational exposures are controlled at the level set by the exposure limit. Also, some substances can be absorbed by direct contact with the skin and mucous membranes in addition to being inhaled, which contributes to the individual's overall exposure.

Most OELs are expressed as a TWA exposure. A TWA refers to the average exposure during a normal 8to 10-hour workday. Some chemical substances and physical agents have recommended STEL or ceiling values where adverse health effects are caused by exposures over a short period. Unless otherwise noted, the STEL is a 15-minute TWA exposure that should not be exceeded at any time during a workday, and the ceiling limit is an exposure that should not be exceeded at any time.

In the United States, OELs have been established by federal agencies, professional organizations, state and local governments, and other entities. Some OELs are legally enforceable limits, while others are recommendations. The U.S. Department of Labor OSHA PELs (29 CFR 1910 [general industry]; 29 CFR 1926 [construction industry]; and 29 CFR 1917 [maritime industry]) are legal limits enforceable in workplaces covered under the Occupational Safety and Health Act of 1970. NIOSH RELs are recommendations based on a critical review of the scientific and technical information available on a given hazard and the adequacy of methods to identify and control the hazard. NIOSH RELs can be found in the NIOSH Pocket Guide to Chemical Hazards [NIOSH 2010]. NIOSH also recommends different types of risk management practices (e.g., engineering controls, safe work practices, employee education/ training, personal protective equipment, and exposure and medical monitoring) to minimize the risk of exposure and adverse health effects from these hazards. Other OELs that are commonly used and cited in the United States include the TLVs recommended by ACGIH, a professional organization, and the WEELs recommended by the American Industrial Hygiene Association, another professional organization. The TLVs and WEELs are developed by committee members of these associations from a review of the published, peer-reviewed literature. They are not consensus standards. ACGIH TLVs are considered voluntary exposure guidelines for use by industrial hygienists and others trained in this discipline "to assist in the control of health hazards" [ACGIH 2012]. WEELs have been established for some chemicals "when no other legal or authoritative limits exist" [AIHA 2012].

Outside the United States, OELs have been established by various agencies and organizations and include both legal and recommended limits. The Institut für Arbeitsschutz der Deutschen Gesetzlichen Unfallversicherung (IFA, Institute for Occupational Safety and Health of the German Social Accident 


\section{Appendix: Occupational Exposure Limits and Health Effects (CONTINUED)}

Insurance) maintains a database of international OELs from European Union member states, Canada (Québec), Japan, Switzerland, and the United States. The database, available at http://www.dguv.de/ifa/ en/gestis/limit values/index.jsp, contains international limits for over 1,500 hazardous substances and is updated periodically.

Employers should understand that not all hazardous chemicals have specific OSHA PELs, and for some agents the legally enforceable and recommended limits may not reflect current health-based information. However, an employer is still required by OSHA to protect its employees from hazards even in the absence of a specific OSHA PEL. OSHA requires an employer to furnish employees a place of employment free from recognized hazards that cause or are likely to cause death or serious physical harm [Occupational Safety and Health Act of 1970 (Public Law 91-596, sec. 5(a)(1))]. Thus, NIOSH investigators encourage employers to make use of other OELs when making risk assessments and risk management decisions to best protect the health of their employees. NIOSH investigators also encourage the use of the traditional hierarchy of controls approach to eliminate or minimize identified workplace hazards. This includes, in order of preference, the use of (1) substitution or elimination of the hazardous agent, (2) engineering controls (e.g., local exhaust ventilation, process enclosure, dilution ventilation), (3) administrative controls (e.g., limiting time of exposure, employee training, work practice changes, medical surveillance), and (4) personal protective equipment (e.g., respiratory protection, gloves, eye protection, hearing protection). Control banding, a qualitative risk assessment and risk management tool, is a complementary approach to protecting employee health that focuses resources on exposure controls by describing how a risk needs to be managed. Information on control banding is available at http://www.cdc.gov/niosh/topics/ ctrlbanding/. This approach can be applied in situations where OELs have not been established or can be used to supplement the OELs, when available.

\section{References}

ACGIH [2012]. 2012 TLVs $®$ and BEIs $®$ : threshold limit values for chemical substances and physical agents and biological exposure indices. Cincinnati, $\mathrm{OH}$ : American Conference of Governmental Industrial Hygienists.

AIHA [2012]. AIHA 2012 Emergency response planning guidelines (ERPG) \& workplace environmental exposure levels (WEEL) handbook. Fairfax, VA: American Industrial Hygiene Association.

CFR. Code of Federal Regulations. Washington, DC: U.S. Government Printing Office, Office of the Federal Register.

NIOSH [2010]. NIOSH pocket guide to chemical hazards. Cincinnati, OH: U.S. Department of Health and Human Services, Centers for Disease Control and Prevention, National Institute for Occupational Safety and Health, DHHS (NIOSH) Publication No. 2010-168c. [http://www.cdc.gov/niosh/npg/]. Date accessed: December 2012. 


\section{This page left intentionally blank.}




\section{This page left intentionally blank.}


The Hazard Evaluations and Technical Assistance Branch (HETAB) of the National Institute for Occupational Safety and Health (NIOSH) conducts field investigations of possible health hazards in the workplace. These investigations are conducted under the authority of Section 20(a)(6) of the Occupational Safety and Health Act of 1970, 29 U.S.C. 669(a)(6) which authorizes the Secretary of Health and Human Services, following a written request from any employer or authorized representative of employees, to determine whether any substance normally found in the place of employment has potentially toxic effects in such concentrations as used or found. HETAB also provides, upon request, technical and consultative assistance to federal, state, and local agencies; labor; industry; and other groups or individuals to control occupational health hazards and to prevent related trauma and disease.

Mention of any company or product does not constitute endorsement by NIOSH. In addition, citations to websites external to NIOSH do not constitute NIOSH endorsement of the sponsoring organizations or their programs or products. Furthermore, NIOSH is not responsible for the content of these websites. All Web addresses referenced in this document were accessible as of the publication date.

This report was prepared by Mark M. Methner of HETAB, Division of Surveillance, Hazard Evaluations and Field Studies. Industrial hygiene equipment and logistical support was provided by Donald Booher and Karl Feldmann. Analytical support was provided by Landauer, Glenwood, Illinois. Health communication assistance was provided by Stefanie Brown. Editorial assistance was provided by Ellen Galloway. Desktop publishing was performed by Mary Winfree.

Copies of this report have been sent to union and management representatives at the facility, the state health department, and the Occupational Safety and Health Administration Regional Office. This report is not copyrighted and may be freely reproduced. The report may be viewed and printed at http:// www.cdc.gov/niosh/hhe/. Copies may be purchased from the National Technical Information Service at 5825 Port Royal Road, Springfield, Virginia 22161. 
Below is a recommended citation for this report:

NIOSH [2012]. Health hazard evaluation report: evaluation of radon exposure at

a government facility - Maine. By Methner M. Cincinnati, OH: U.S. Department of

Health and Human Services, Centers for Disease Control and Prevention, National Institute for Occupational Safety and Health, NIOSH HETA No. 2011-0031-3167.

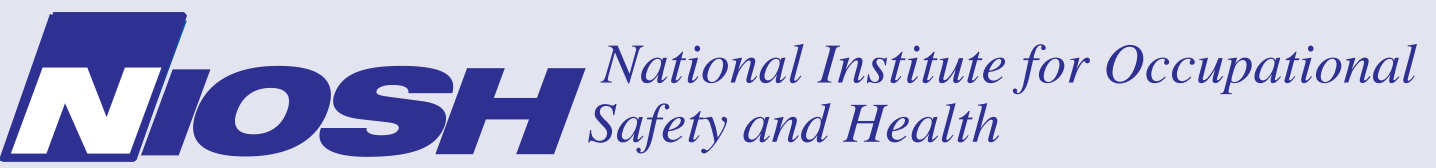

Delivering on the Nation's promise: Safety and health at work for all people through research and prevention.

To receive $\mathrm{NIOSH}$ documents or information about occupational safety and health topics, contact NIOSH at:

1-800-CDC-INFO (1-800-232-4636)

TTY: 1-888-232-6348

E-mail: cdcinfo@cdc.gov

or visit the NIOSH web site at: www.cdc.gov/niosh.

For a monthly update on news at $\mathrm{NIOSH}$, subscribe to $\mathrm{NIOSH}$ eNews by visiting www.cdc.gov/niosh/eNews. 